\title{
THE POLISH EDUCATION SYSTEM TODAY: AN INTERVIEW WITH KATARZYNA POTYRALA
}

\author{
Vincentas Lamanauskas \\ Šiauliai University, Lithuania
}

It is without doubt that education and teaching is a key to a better life quality of society. Many countries accentuate education quality, keeping the latter a priority of all education system. The Polish education system has faced various changes over the last few years. The Polish education system is close to the Lithuanian system, it distinguishes itself in deep traditions. It is always interesting what challenges are encountered abroad, how the education process is organized, what teaching and learning environment looks like, what challenges the 21 st century education meets. One can notice that school, municipality and community collaboration is extremely vivid in Polish schools, a very great attention is devoted to history and geography, patriotism and citizenship education. This is also very important for Lithuanian education. Both Lithuanian and Polish education become not resistant to the influence of globalization. As Duoblienè notices (2011), globalization leaves less and less space for separate states to solve problems, especially in education sphere. For example, regardless that Poland is a much bigger state than Lithuania concerning both territory and

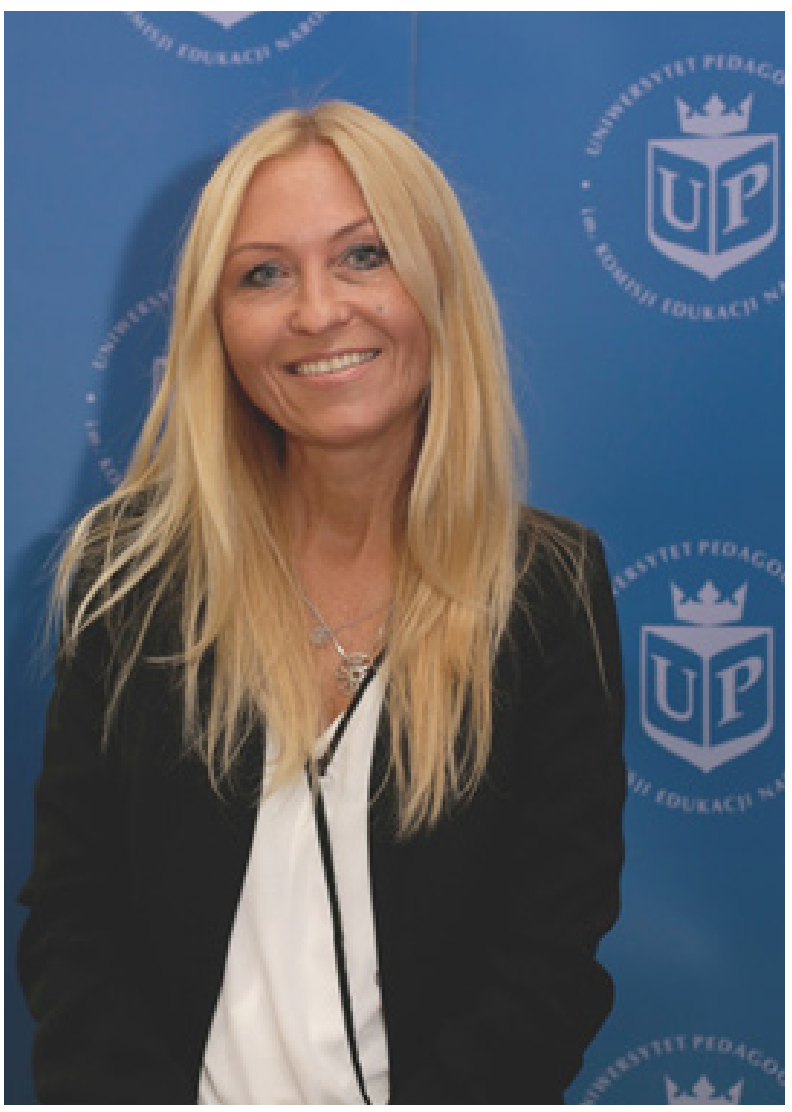
population, similar problems are characteristic of both countries. For example, in Poland the same as in Lithuania are observed poor demographic tendencies, emigration and other.

The previous time (Lamanauskas, 2017) we were talking with professor Anna KlimKlimaszewska from the Siedlce University of Natural Sciences and Humanities. This time we are talking with Kracow pedagogical university professor Katarzyna Potyrala.

Dr. Katarzyna Potyrala is a professor of pedagogy. She works at the Pedagogical University of Cracow (in Polish: Uniwersytet Pedagogiczny im. Komisji Edukacji Narodowej w Krakowie), Poland. She has many years of experience in scientific and pedagogical work. By the way, it is the oldest Pedagogical University in Poland. At present, K. Potyrala is also a Vice-Rector of the 
University. The professor's field of scientific interest is extremely wide, for example, the didactic transformation of the content of education in formal, nonformal and informal education; scientific communication in a wide public space; learning models and metacognitive compe-tences of users of various types of teaching media etc.

\section{Introduce yourself briefly to the journal readers}

K. P. I specialize in didactics and media pedagogy, I am a biologist, professor of Pedagogical University of Krakow, where I have been working since 1998. I am interested in the didactic transformation of knowledge at various levels of education and to a wide public space through new and old media. In my research I use information technology but also analog images. I am interested in the history and popularization of science and the history of photography, and I devoted two co-author monographs to these issues: Scientific Theater (in cooperation with D. Raichvarg and E. Di-Scala) and Photography and didactics (in cooperation with J. R. Paśko). Didactical media, however, interest me much more widely what was reflected in the monograph entitled iEducation - synergy of new media and didactics. Evolution, antinomies, contexts. The synergy phenomenon is interesting because it always leads to something new and activities that give better results. When dealing with digital technologies in connection with education, one cannot ignore the problem of threats in the digital world and various levels of digital literacy and scientific literacy. This is the subject of the last monograph, which I wrote with Łukasz Tomczyk and entitled Digital security of children and youth in the perspective of media pedagogy. I am the head of the Department of Didactics and Methodology of Educational Research at the Institute of Educational Sciences and Vice-Rector of the Pedagogical University in Krakow for student affairs. I work intensively with teachers and participate in debates about teacher training.

\section{It would be interesting to know a bird's-eye-view of the education system in your country in general, that is from primary to tertiary level. Can you describe the education system in your home country?}

K. P. Until the 1990s, there was only one form of compulsory education - compulsory schooling in an 8-grade elementary school. As part of the reform of the educational system implemented since September 1999, compulsory education was extended by one year as part of the structure introducing a six-year primary school and a three-year junior high school.

After the enactment and entry into force of the Act - Educational Law (from September 1, 2017), compulsory schooling is again fulfilled in an 8-grade elementary school, while compulsory education will be fulfilled in accordance with this Act by attending a public or private post-primary school or implementing vocational training at the employer.

Currently, primary school is divided into two stages: the first stage corresponds to grades I to III and offers integrated early school education, while the second stage is grades IV to VIII. In the years 2002-2015, after completing six-year primary school, students took obligatory tests carried out by the district examination committees and evaluated by the examiners qualified by these committees. These tests, which had only an informative role (they were not exams in the strict sense and did not decide to continue education), were abolished by law. On the other hand, starting from the 2018/2019 school year, students in the eighth grade of primary school will take the universal, external eighth grade exam. 
Until the 1999/2000 school year, graduates of an 8-year primary school could continue their education in a 4-year general high school, a 4-5-year vocational technical college, a 4-year vocational or technical high school and a 3-year basic vocational school. After completing the first four types of schools, students could take the secondary school-leaving examination (matura), which grants access to universities. Those who did not pass the secondary school-leaving examination or were not admitted to higher education could continue their education in post-secondary schools (education in this type of school lasts from 1 to 2 / 2.5 years). Graduates of basic schools (in the old structure of education) entered the labor market with the qualifications of a skilled worker.

After the first reform of the school system from the 1999/2000 school year (pursuant to the Act of 8 January 1999), all graduates of a 6-year primary school continued their education in a 3-year junior high school. At the end of junior high school, students took a compulsory external examination conducted by the district examination commission. According to the original as-sumptions of this reform, after graduating from junior high school, students were to choose from two options: a 3-year profiled high school (ending with a high school diploma) or a 2-year basic vocational school.

Finally, the Act on the education system established the following possibilities for continu-ing education by junior high school graduates:

- in a three-year basic vocational school, the completion of which allows obtaining a diploma confirming professional qualifications after passing examinations confirming qualifica-tions in a given profession, as well as further education starting from the second grade of general high school for adults,

- in a three-year general high school, the completion of which allows obtaining a secondary school-leaving certificate after passing the matriculation examination,

- in a four-year technical college, whose completion allows you to obtain a diploma confirming professional qualifications after passing the examinations confirming qualifications in a given profession, as well as to obtain a secondary school-leaving certificate after passing the matriculation examination,

- in post-secondary school for people with secondary education, with a teaching period of no more than 2.5 years, enabling them to obtain a diploma confirming professional qualifica-tions after passing examinations confirming qualifications in a given profession,

- in a special three-year school preparing for work for students with moderate or severe mental retardation and for students with linked disabilities.

The matriculation examination has replaced the university entrance exams and is external. The Act on the education system has introduced an external high school final exam since spring 2005.

Another reform of the school system from December 2016 leads to a partial return to the assumptions of the school system in force before 1999. After its implementation, the structure of the Polish education system consists of the following types of schools:

a) 8-year primary school - compulsory for all students;

b) Secondary (secondary and post-secondary) schools:

- 4-year high school,

- 5-year technical college,

- 3-year industry first degree school,

-3-year special school preparing for work, 
- 2-year industry second degree school (continuation of education at 3-year industry first degree school),

- A maximum of 2.5 years post-secondary school for people with secondary or industry secondary education.

In the currently implemented school system there will be two external exams: eighth grade and matura exam.

\section{It is obvious that teaching is a very important profession. Teachers need to be well- educated. How teachers are educated in your country?}

K. P. Yes, formal education is especially important in the situation of complex social structures and extensive knowledge boundaries. It is the school that should help in the processing of information, the acquisition of structured knowledge and the formation of appropriate attitudes. Formal education also plays a significant role in the situation of universal access to knowledge thanks to the media, which shape and redefine ideas and values in their own way. Teacher preparation for these challenges is a priority. This preparation must also take into account the fact that in a situation where the core curriculum can be at the same time a teaching program, teachers par-ticipating in determining the content of education, student activities and teaching situations, play an important role in preparing learners for continuous adaptation in the world of information and media explosion cyberspace.

Contemporary society is changing so quickly that it is difficult to adapt permanently and prepare for the future. At present, university teacher training has been put in place of the need to quickly adapt to change. The anxiety of universities educating teachers responsible for the graduate profile of teacher specialties and adaptation of teachers' competences and qualifications to the expectations of employers in the reformed school is justified. Teacher education is currently continuous in the field of pre-school and early school education and special education (5-year Master's degree) and a two-level $(3+2)$ character in other fields of education for teachers of var-ious school subjects. However, a new provision has appeared which obliges universities to admit firstdegree graduates of the same degree to the second degree. The first degree (bachelor's degree) does not currently give entitlement to work as a teacher at school. In addition, teachers can only be educated by universities that meet the highest criteria for the quality of education. Thus, there is a great emphasis on high quality teaching and preparation of teachers at the highest level.

\section{When should children start formal schooling in your country?}

K. P. Currently, compulsory education is divided into:

- compulsory annual pre-school preparation,

- compulsory education, which starts at the beginning of the school year in the calendar year in which the child turns 7 , and lasts until the completion of primary school, but no longer than until the age of 18 ,

- compulsory education up to the age of 18 , which can be fulfilled primarily by attending a secondary school or by providing professional training for an employer.

Pre-school education is intended for children from 3 years old. From 2004/05, children over 6 years old had to attend kindergartens or kindergarten departments organized in 
primary schools, as the law introduced compulsory annual pre-school preparation. From September 2011, this obligation applied to 5-year-olds; since 2015 again includes 6-year-old children.

In the school years 1999 / 2000-2016/2017, children from 7 to 13 years old attended an elementary school in which education lasted 6 years. From September 1, 2017, the Polish legislator restored a pre-existing, 8-grade primary school. Graduates of the sixth grades of the current six-year school from the 2017/2018 school year continue their education in the seventh and eighth grades of the eight-year school.

It is a well-known fact that students' motivation to learn is a key element in education. If children are motivated to learn and if we enable each one to learn effectively, we will have an education system with a great performance level. What about students' motivation to learn in your country?

K. P. School achievements of students largely depend on their personal characteristics, such as self-discipline, perseverance, commitment, motivation to work, a sense of responsibility for the effects of their work and the ability to organize time and work, allowing for independent, timely implementation of tasks. The motivations of students to learn are various and may change during school education, along with learning about the specific learning characteristics of a given school subject or changing life priorities. I think that, like everywhere in Poland, an important motivation to learn is high competition on the labor market and willingness to implement professional plans. In the past, graduating from a good school and study was a significant motivation. Today, the fact of graduating from school and studies does not guarantee economic success. It is so complicated that motivation must be constantly strengthened by student.

Maintaining the original initial motivation and mobilizing for systematic work requires a lot of effort on the part of the student and the use of various motivational techniques. Not everyone is determined enough to achieve their goals. When it comes to teaching and learning at school, it is recognized that knowing the expectations and fears of students about cognitive processes, strengthening the role of the teacher as the organizer of the learning process and facilitator, and strengthening motivating factors during learning will improve the model teaching-learning in var-ious educational environments. Polish school is moving step by step in this direction to make the student's educational experience more important than the implementation of the curriculum. However, this is still a long way to go.

\section{What are the qualities of a good teacher from your point of view?}

K. P. I think everyone met a teacher on their way, whom he could say: he is a good teacher. In this matter, there are not too many changes: wisdom, ability to transfer knowledge, supporting and motivating students, self-improvement, fair assessment. In a globalizing world, it is neces-sary to add openness and tolerance for otherness, skillful information processing thanks to infor-mation technology tools and so-called new media and communication skills. For me, the authori-ty is a person who has deep knowledge, is open to others and new knowledge, and above all goes out to others by sharing knowledge, while discovering areas of his ignorance and constantly learning. 


\section{It is clear that each country's education system has both advantages and disadvantages. Could you briefly describe your country's basic education system challenges?}

K. P. An important challenge in my country is constantly adapting the school to the reforms of education. A great advantage is the rapid response of universities to the needs of teachers in this area. However, the current education reform has introduced a lot of confusion, such as double years-old in the first grade of high school (students after „new” eighth grade and after the last grade of "old" junior high school, met in the first grade of „new” secondary school), different primary knowledge of high school students, too many classes, problems with recruiting to high schools and more. For me as a scientist, naturalist, it is unacceptable that we have moved away from holistic science education in grades IV-VI of a six-grade elementary school in favor of sub-ject education in grades V-VIII of the current eight-grade elementary school. Science remained only in grade IV of primary school as a combination of biological and geographical content. We don't have a typical subject „Science", like in most European countries. These changes have also resulted in many changes in teacher training.

\section{$* * *$}

Thus, as you can see, education reforms in neither country are carried out simply and with-out difficulties. One can always encounter certain challenges. One can dare to say that education will further remain an actual sphere in which changes are necessary because this sector forms the foundation of the state's future. This suits both for Lithuania and Poland. The situation in the change of the education system depends on all of us. If one wants to have an education system corresponding to nowadays challenges and reality, then, first of all, one has to think over and to come to an agreement what it has to be. Reforms due to reforms do not solve problems. As Walaszek and Bakowska (2016) noticed, the current state of the Polish education system is a result of a long-term socio-economic transformation. One cannot think that there will be no trans-formations in future. It is hardly possible to create an ideal education system. Education quality of any country is determined by a lot of factors, the essential of which are traditions and culture of a particular country. However, it remains clear that one can collaborate, learn from each other and better cognize each other.

On behalf of the journal's editorial board we wish the professor success in her academic career.

\section{References}

Duoblienè, L. (2011). Ideologizuotos švietimo kaitos teritorijos [Ideological territories of education change]. Vilnius: Vilniaus universiteto leidykla.

Lamanauskas, V. (2017). Education actualities in Poland: An interview with Anna Klim-Klimaszewska. Švietimas: politika, vadyba, kokybé / Education Policy, Management and Quality, 9(3), 151-156.

Walaszek, M., \& Bakowska, E. (2016). Organisation and diversification of the educational market in Poland: The case of the Poznań agglomeration. Quaestiones Geographicae, 35(2), 105-114. 
Note: This interview was performed 05 November 2019, in Cracow, Poland.

Received 15 November 2019; accepted 02 December 2019

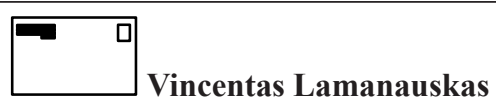

PhD., Professor, Institute of Education, Siauliai University, P. Visinskio Street 25,

LT-76351 Siauliai, Lithuania.

E-mail: vincentas.lamanauskas@su.lt

Website: http://www.lamanauskas.puslapiai.lt

https://www.researchgate.net/profile/Vincentas_Lamanauskas 